\title{
THE EFFECT OF CORPORATE GOVERNANCE DISCLOSURE ON INVESTOR REACTIONS WITH PROFITABILITY AS MODERATING VARIABLE
}

\author{
Hariadi Krisna Langit*, Sutrisno, Rahman Aulia Fuad \\ School of Graduate Studies, Faculty of Economics and Business, \\ University of Brawijaya, Indonesia \\ *E-mail: krisna.langit.92@gmail.com
}

\begin{abstract}
The aim of this research is to understand how Corporate Governance affects investor's reaction in capital market by profitability as a moderating variable. This research uses secondary data obtained from Indonesian Stock Exchange. Investor's reaction is measured by Cumulative Abnormal Return, which happened around the time of annual report publication. Corporate Governance are measured by Institutional ownership, ownership by board of commissioner, audite commite, and independent commissioner. Profitability as moderating variabel is measured by Return on Asset. This research was done to 25 companies which were listed in Indeks LQ 45 in Indonesian Stock Exchange during 20152016. Data analysis techniques used in this research are regresion analysis and moderated regresion analysis (MRA). The result shows that corporate governance (Institutional ownership, ownership by board of commissioner, audite commite, and independent commissioner) negatively affect Cumulative Abnormal Return. Profitability as a moderating variable was able to explain the relationship of corporate governance (ownership by board of commissioner and audite commite) affect significantly to Cumulative Abnormal Return partially. Corporate governance does not have any impact to Cumulative Abnormal Return value, because of the implementation of corporate governance in Indonesia is not provide optimum results mean while in the process of considering corporate governance practices take time to know the benefits.
\end{abstract}

\section{KEY WORDS}

Cumulative abnormal return, investor's reaction, corporate governance, economy, benefits.

According to Nogi the purpose of an established company is to increase the value of the company by providing benefits and increase the prosperity of the owner or its shareholders (Nogi, 2003: 116). However, managers as corporate managers have different objectives, especially in terms of increasing individual achievement and compensation, which will lead to falling investor expectations about returns on the funds they have incurred. This is in line with Agency Theory which says that there is a difference of interest between principal and agent. Therefore, the need for a system that bridges the separation of interests between owners and managers within a company. This separation is expected to align the interests of owners or shareholders with the interests of managers as managers of the company. The system is with corporate management (Good Corporate Governance - GCG). Given Corporate Governance (CG) is expected to serve as a tool to give investors confidence that they will receive return on the funds they have invested.

In addition, based on the phenomenon that occurs, the insistence on the implementation of corporate governance caused by the existence of World Bank report in 1999 (Sutedi, 2011: 50). The report explained that the economic crisis in East Asia was caused by systematic failure of corporate governance practices derived from weak legal framework systems, inconsistent accounting standards and auditing standards, poor banking practices, ineffective supervision, and lack of rights Minority shares. In its review, the Asian Development Bank draws the conclusion that the economic crisis affecting ASEAN countries is the result of a bad corporate governance system in the economy.

Corporate governance is a concept for improving corporate performance through the formation of common goals and supervision of management performance and ensures 
accountability of management to stakeholders by basing on the regulatory framework (Nasution and Setiawan, 2007). Owen (2005) says that Enron's case in America has led companies to pay more attention to more transparent reporting and upholding corporate social independence and accountability.

Related to this, there are some researchers who relate it to investor reactions that are reflected from abnormal return. Indriastuti (2011) analyzed the Influence Principles of corporate governance on Abnormal Return, with the results of the principles of corporate governance proved to have a significant effect on abnormal return. In addition, other researchers in line with Tristiarini (2005), analyzed the Influence of Corporate Governance Implementation on Abnormal Return at the Financial Statement Announcement 2003. With the result that the implementation of corporate governance proved to have a positive effect on abnormal return.

Different results were performed by other researchers, such as Pratiwi and Suryanawa (2014). With the results of corporate governance research has no significant effect on stock returns, because it has not been able to attract investors to invest their capital. Another research with the same results done by Budiharjo (2016), With the results of research found that corporate governance does not affect the stock return.

Information is considered useful if the information can change the confidence of investors. Information about the company is required by the investor to serve as the basis for making the decision to invest in the company or not, this is in line with the theory of signaling. The Signaling Theory stresses the importance of companies having a desire to provide information to those in need. The importance of information because information presents things that happen in the company whether that happened in the past, the present, or to predict future events and to know the stock market.

One of the information that can be used in analyzing company performance to predict stock return is profitability ratio. Profitability ratio describes the ability of companies in generating profits from sources of funds owned (Untung and Sugiono, 2008). The greater the level of corporate profits indicates that the better the management in managing the company.

Based on background explanation above problem, the difference of research result that make it research gab research so that need to be researched by entering company profitability information as moderating variable derived from signaling theory as described previously.

People, especially investors, have learned a lot from the recent cases and accounting scandals as a result of weak corporate governance practices. Therefore, the researcher is interested to further investigate investor's reaction to corporate governance practices.

Description of problem formulation:

- Does corporate governance practice affect investors' reactions to companies listed in the LQ 45 period 2015-2016?

- Does the profitability of firms reinforce the relationship of corporate governance practices to investor reactions to companies listed in LQ 45 period 2015-2016?

The purpose of this study:

- Test and analyze the influence of corporate governance practices on Investor reactions on companies listed in LQ 45 period 2015-2016.

- Testing and analyzing the profitability of the company strengthens the relationship of corporate governance practices to investor reactions on companies listed in LQ 45 period 2015-2016.

Contribution of Research. Providing input for the development of theory, especially Agency Theory, which underpins the emergence of corporate governance mechanisms. Based on the results of the research can be used to add test evidence empirically to researches that have been done previously. In addition, provide input thoughts for investors to be the basis of decision making in investing. 


\section{LITERATURE REVIEW}

Agency Theory. Jensen and Meckling (1976) stated that Agency theory has two distinct interests in a company, namely agent and principal. Therefore, a new instrument is needed that is Corporate Governance to ensure that management is running well in accordance with the company's vision and mission (Siallagan and Machfoedz, 2006). Corporate governance deals with how investors believe that managers will benefit them, that managers will not steal / embezzle or invest into unprofitable projects with funds invested by investors, and how investors control Managers (Shleifer and Vishny, 1997) in (Ujiyanto and Pramuka, 2007).

Information Asymmetry Theory. One of the conditions causing the difference in information between the agent and the principal, in addition to the agency problem is information asymmetry which results in the great chance of managers to do things that are beneficial to their interests. According Husni (2012) some companies that run business transactions will likely have an advantage in terms of information than others.

Signaling Theory. Signalling theory explains why firms have an incentive to provide financial statement information to outsiders. Firms can increase company value by reducing asymmetry information. One way to reduce asymmetry information is to signal external parties (Lokollo and Syafruddin 2013). The provision of this information may make the external party more confident about the profit distributed by the company in its financial statements is purely a result of company performance is not a profit direkayasakan by the company in order to provide a positive signal for external parties (Lokollol and Syafruddin 2013).

Brigham and Houston (2009) state that cues are an action taken by a company management that gives investors a clue as to how management looks at a company's prospects. The conclusion that profitability ratios will signal investors and make the market more likely to react positively if the market interprets an improved profitability ratio as a bright signal and a bright outlook for the company in the future. Basic selection of these variables, where the company gives a positive signal to investors who are expected to affect the cumulative abnormal return of positive stocks as well.

Good Corporate Governance. In corporate governance there are 4 indicators based on the principles of Good Corporate Governance (KNKG, 2006: 5-7), which consists of:

Institutional Ownership. According Kartikasari (2011), institutional ownership is the ownership of shares of companies by financial institutions such as insurance companies, banks, pension funds, and investment banking. The greater the institutional ownership the more efficient the utilization of company assets. Institutional ownership generally acts as a party to monitor the company in general and managers as managers of the company in particular.

Management Ownership. Jensen and Meckling (1976) stated that to minimize agency conflict is to increase managerial ownership within the company. Managerial ownership is the ownership of a company's shares by the management. With managerial ownership, management not only functions as a company manager but also as a shareholder. Ross et al (in Naftalia, 2013) states that the greater the ownership of management within a company then management will tend to seek to improve its performance for the benefit of shareholders and for its own interests.

Audit Committee. According to Ningsaptiti (2010), the audit committee has the primary responsibility to assist the board of commissioners in carrying out its responsibilities primarily with issues related to the company's accounting policies, internal controls, and financial reporting systems. Based on the Circular Letter of the Jakarta Stock Exchange Circular Number SE-008 / BEJ / 12-2001, the membership of the audit committee shall consist of at least three persons including the chair of the audit committee. Gradiyanto (2012) revealed that the audit committee is closely related to the review of the risks facing the company and the compliance of applicable regulations.

Independent Commissioners. In Naftalia (2013), an independent commissioner is a mechanism that oversees and guides the management of the company. In general, independent board of commissioners is responsible for overseeing the performance of the 
company's management, and the realization of accountability. The existence of an independent commissioner of an enterprise may affect the integrity of a financial statement produced by management.

Basic Concept of Stock Return. According Jogiyanto (2015: 416), return is the result of investment. There are two types of stock returns, namely return on realization and expected return. Return realization is a return that has occurred that is calculated based on historical data. While the expected return is the expected return of investors in the future.

Basic Concept of Profitability. ROA is one of several profit ratios (profitability ratio). $\mathrm{ROA}$ is an indicator that is widely used by investors because ROA calculates the return on assets and investments made by investors in a company. According to Horne and Wachowicz (2012) high ROA often reflects the company's acceptance of good investment opportunities and cost-effective management. According to Harahap (2009), the greater the ROA ratio the better because the company is considered capable of using assets owned effectively to generate profits. This means that ROA can be used by investors in assessing the company's ability to generate profits on assets owned.

\section{RESEARCH CONCEPT FRAMEWORK}

Conceptual Framework for Research. Corporate governance mechanisms consist of institutional ownership, management ownership, audit committees, and independent commissioners. Other information that allegedly contributed to the existence of Abnormal Return shares is the ratio of profitability. According Harahap (2009) profitability ratio is the ability of the company's management in gaining overall profit. To better understand how the thinking of this research, then made a flowchart of research thinking. The flowchart of the conceptual framework of this study is as follows:

Corporate governance Profitability Investor Reaction

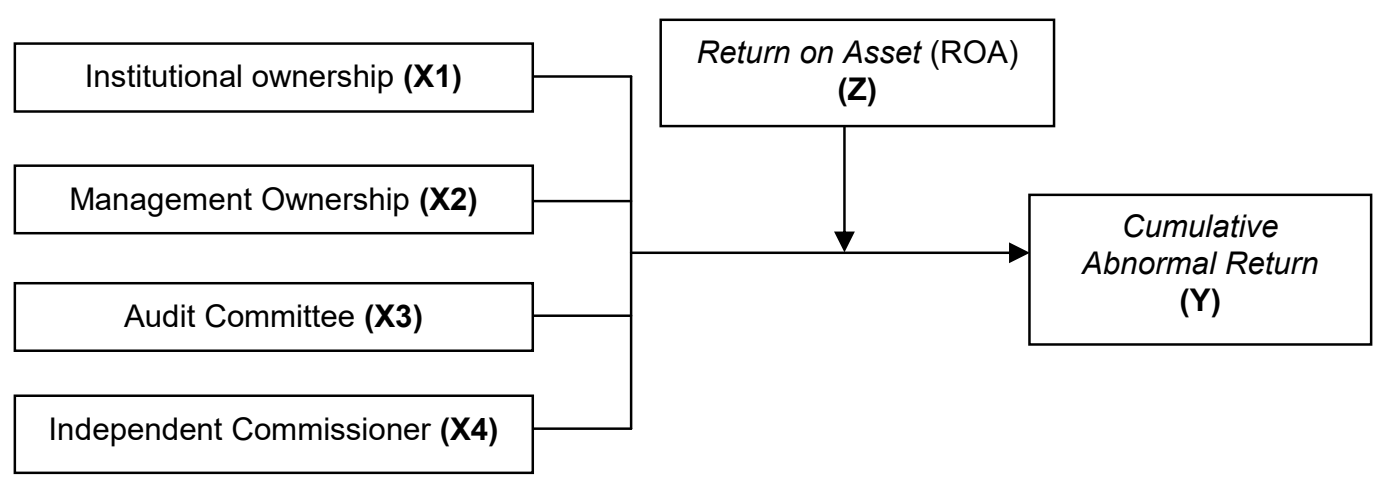

Figure 1 - Conceptual Research Framework

Development of Hypotheses:

With the implementation of corporate governance is expected to provide more value that is visible from the abnormal return of the company concerned. Moreover, coupled with the information company profitability ratios. Then the hypothesis in this study as follows:

Effect of Institutional Ownership on CAR. The first component of corporate governance in this study is institutional ownership. With dominant ownership by institutional investors, the supervision and analysis carried out on an enterprise will be conducted strictly than for minority investors. Research by Robert and Yuan (2006) shows that institutional ownership can significantly reduce lending costs. (Shleifer \& Vishny, 1997) stated that institutional investors play an important role in creating corporate governance systems within the company by independently overseeing management to respond to management policies that are not considered effective in managing the company.

$\mathrm{H} 1 \mathrm{a}$ : Institutional ownership is related to CAR. 
Effect of Institutional Ownership on CAR moderated by ROA. Institutional ownership is the percentage of shares owned by the shareholder institution. The results of the study by Cyert et al. (1998) found that sole and dominant ownership (blockholder) had a significant effect on firm value. In this case Holderness and Sheehan (1988) specifically find a significant positive influence between blockholder against cumulative abnormal return of stock. This opinion is supported by empirical evidence from Barclay and Holderness (1990), which suggests that a significant positive effect on the degree of institutional ownership of a company's value. Pound (1998) discloses that individual investors with low shareholding rates have a tendency to utilize or borrow voting power owned by majority shareholders to oversee management performance. While the research conducted Sudarma (2003) found different results that institutional ownership negatively affect the value of the company. Researchers suspect there are other factors that support one of the factors of institutional ownership of the abnormal return of shares of ROA. So from the results of this study is expected to bridge the differences of research results into research GAB this research.

$\mathrm{H} 1_{\mathrm{b}}$ : ROA strengthens the institutional ownership relationship to CAR.

Effect of Management Ownership on CAR. The separation between ownership and management of a company has the potential to create agency conflicts based on different interests. Differences of interests between management and shareholders may cause harm to either party. This is because of the different objectives between managers and shareholders, on the one hand management is responsible for increasing shareholder wealth from funding received, but management also wants to expand its business further with the benefits gained from the results of the management company. Research conducted by Soliha \& Taswan (2002) also found a significant and positive relationship between management ownership of firm value. Thus, it can be assumed that agency conflicts can be minimized if management also has a share of ownership within the company.

$\mathrm{H} 2_{\mathrm{a}}$ : Ownership of management has an effect on CAR.

Effect of Management Ownership on CAR is moderated by ROA. Management ownership is the percentage of shares owned by executives and directors. Ownership management is an important issue in agency theory since it was published by Jensen and Meckling (1976). The results of Rahayu and Faisal (2005) stated that the greater the projected ownership of management in a company then management will work harder to meet the interests of shareholders who are also themselves. While Sudarma (2003) who found that managerial ownership does not significantly affect the value of the company. Researchers suspect there are other factors that support one of the factors of institutional ownership of the abnormal return of shares of ROA. So from the results of this study is expected to bridge the differences of research results into research GAB this research.

$\mathrm{H} 2_{\mathrm{b}}$ : ROA strengthens the ownership relationship of management to CAR.

Effect of the Audit Committee on CAR. The Company is required to have an Audit Committee as a fulfillment of corporate governance practices (Turley and Zaman, 2004). The existence of an audit committee is enabled to assist the board of commissioners in reviewing the results of the company's financial statements, the company's compliance with the rules indicating that the existence of the audit committee is related to the integrity of the company's financial statements. This is supported also by Turley and Zaman (2004) research that examines the influence of corporate governance and audit committees, found that evidence suggests a positive relationship between the audit committee and the quality of financial statements and company performance.

$\mathrm{H}_{\mathrm{a}}$ : Audit Committee influences the cumulative abnormal return of shares moderated by ROA.

ROA moderates the influence of the Audit Committee on CAR. According to Siallagan and Machfoedz (2006) stated that the audit committee has the duty of assisting the board of commissioners to ensure that the company has presented the financial statements fairly in accordance with generally accepted accounting principles, the company has implemented internal control, risk management and corporate governance, external audit function And internal audit has been running well. When reporting quality gets better, then the value of stock prices will increase. This is supported also by Turley and Zaman (2004) found that 
evidence indicates a positive relationship between the existence of the audit committee with the quality of financial statements and company performance against stock prices. However, research conducted by Ramdiani and Yadnyana (2013) concluded that statistically the number of audit committee members has no effect on stock prices. Researchers suspect there is another factor that is ROA. So from the results of this study is expected to bridge the differences of research results into research GAB this research.

$\mathrm{H}_{\mathrm{b}}$ : ROA strengthens the audit committee's relationship to CAR.

Effect of Independent Commissioners on CAR. Dengan adanya kondisi komisaris independen yang baik, pengawasan terhadap transparansi, akuntabilitas, dan praktek keadilan dapat lebih terjamin (Susiana dan Herawaty, 2007). Penerapan tata kelola perusahaan yang berkualitas dapat mempersingkat proses bisnis, dan hal tersebut berujung pada kinerja operasional yang lebih baik dan pengeluaran modal yang lebih rendah, sehingga memberi kontribusi pada pertumbuhan penjualan dan keuntungan yang secara simultan mengurangi kebutuhan dan pengeluaran modal (Gompers, 2001). Penelitian yang dilakukan Chtourou (2001) menunjukkan bahwa komisaris independen secara umum memiliki pengawasan yang lebih baik terhadap manajemen sehingga mempengaruhi kemungkinan kecurangan dalam menyajikan laporan keuangan.

$\mathrm{H} 4_{\mathrm{a}}$ : Komisaris independen berpengaruh terhadap CAR.

Effect of Independent Commissioners on CAR. Given the conditions of good independent commissioners, oversight of transparency, accountability and fairness practices can be more assured (Susiana and Herawaty, 2007). The implementation of good corporate governance can streamline business processes, leading to better operational performance and lower capital expenditure, contributing to sales growth and profits simultaneously reducing capital needs and expenditures (Gompers, 2001). Research conducted Chtourou (2001) shows that the independent commissioner in general has better supervision of the management thus affecting the possibility of fraud in presenting the financial statements.

$\mathrm{H} 4_{b}$ : Independent commissioners have an effect on CAR.

Test of Equation Research Model. MRA equation (Moderating Regression Analysis) statistics of this research are:

Equation I:

$$
C A R=\alpha_{0}+\alpha_{1} K P I N+\alpha_{2} K P M J+\alpha_{3} K M A U+\alpha_{4} K M I N+e
$$

Equation II:

$$
\begin{gathered}
C A R=\alpha_{0}+\alpha_{1} K P I N+\alpha_{2} K P M J+\alpha_{3} K M A U+\alpha_{4} K M I N+\alpha_{5} R O A+\alpha_{6}\left(K P I N{ }^{*} R O A\right)+ \\
\alpha_{7}\left(K P M J{ }^{*} R O A\right)+\alpha_{8}\left(K M A U{ }^{*} R O A\right)+\alpha_{9}\left(K M I N{ }^{*} R O A\right)+e
\end{gathered}
$$

Note:

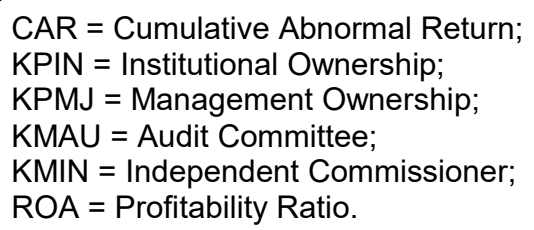

\section{METHODS OF RESEARCH}

This research is a type of hypothesis testing research. Indriantoro and Supomo (2006: 89) states that, Research that aims to test the hypothesis (hypothesis testing) is generally a study that explains the phenomenon in the form of relationships between variables.

Population and Sample Determination. The population in this study are all companies listed on the Indonesia Stock Exchange. Selection of sample using purposive sampling method, with criterion:

1. Companies listed on the Indonesia Stock Exchange 2015-2016

2. Companies listed in the LQ 45 Index for the period 2015-2016 
3. Companies that issue annual reports for the period 2015-2016.

4. The Company displays data on the date of submission of annual report to Bapepam for the period 2015-2016..

Types and Data Sources. The data in this study is polled data. This study used a short window period ie three days prior to the publication of the annual report, during the publication of the annual report and three days after the publication of the annual report. Researchers use short-term windows because the amount of information on the market will affect stock prices.

Dependent variable used in this research is CAR. Before calculating the CAR then first calculated the amount of abnormal return, which is the difference between return realitation minus the expected return. In this study, the abnormal return formula used, namely (Hartono, 2009: 558):

$$
\mathrm{RTN}_{\mathrm{i}, \mathrm{t}}=\mathrm{R}_{\mathrm{i}, \mathrm{t}}-\mathrm{E}\left[\mathrm{R}_{\mathrm{i}, \mathrm{t}}\right]
$$

After calculating the amount of abnormal return, then the calculation of cumulative abnormal return which is the sum of abnormal return the previous day in the event period for each securities as follows:

$\mathrm{ARTNi}, \mathrm{t}=\sum_{t-3}^{t+3} R T N i, a$

Institutional ownership is the ownership of shares of companies by financial institutions such as insurance companies, banks, pension funds, and investment banking (Siregar dan Utama, 2005 in Guna and Herawaty, 2010).

$$
\text { KPIN }=\frac{\text { Number of shares owned by institutional investors }}{\text { Total share capital outstanding }}
$$

Ownership of management is a share owned by management in private and shares owned by the relevant company and its affiliates (Susiana and Herawaty, 2007, in Guna and Herawaty, 2010.

$$
\text { KMAU }=\frac{\text { Number of external audit committee members }}{\text { Total of audit committee }}
$$

Audit Committee according to Kep. 29 / PM / 2004 is a committee established by the board of commissioners to perform the task of supervising the management of the company (Isnata, 2008, in Guna and Herawaty, 2010).

$$
\mathrm{KMAU}=\frac{\text { Number of external audit committee members }}{\text { Total of audit committee }}
$$

Independent commissioners are measured using a ratio scale through the percentage of commissioner members coming from outside the company of all sizes of the members of the company's board of commissioners (Isnata, 2008, in Guna and Herawaty, 2010).

$$
\text { KMIN: } \frac{\text { Number of members of the board of commissioners from outside }}{\text { sall members of the board of commissioners of the company }}
$$

This study uses profitability as a moderating variable. Profitability in this research is measured by ROA ratio (Guna and Herawaty, 2010):

$$
\text { ROA }=\frac{\text { Net profit after tax }}{\text { Total Assets }}
$$


Data analysis technique. The classical assumption tests used are:

1. Residual Normality Test;

2. Multicolinearity Test;

3. Heterocedasticity Test;

4. Test Autocorrelation.

Ghozali (2009: 87) states that the accuracy of sample regression function in estimating the actual value can be measured from three things, namely:

1. Coefficient of Determination (R2)

2. Individual Parameter Significance Test ( $t$ test)

\section{RESULTS OF STUDY}

Descriptive Statistics. Based on Table 1 above, several conclusions can be drawn as follows:

1. CAR variables derived from the sample of 50 companies have an average of 0.031 with a standard deviation of 0.338 . The CAR has a positive average indicating that most firms receive a higher than expected abnormal return. The standard CAR deviation score greater than the average indicates that the CAR experienced by the sample company has a relatively large difference.

2. The institutional ownership variable shows the lowest value of 0,000 . This indicates that overall, the company is performing well on its policy of percentage of institutional ownership. The maximum value of this variable can reach 0.991 . The average of this variable as a whole reaches 0.376 with a standard deviation of 0.325 . This means that the company is very concerned about the implementation of policies towards institutional ownership to the public who need information about the company.

3. Managerial ownership variable has a minimum value of 0,000 and a maximum value of 0.920 . The average achieved is 0.036 with a standard deviation of 0.132 . This indicates that almost all firms have relatively high percentage of managerial ownership. Only a small percentage of firms have low managerial ownership percentages.

4. Audit committee variable has an average value of 0.768 with a standard deviation of 0.220 . The lowest value is 0.400 , while the highest value can reach 1,000 . The average value may suggest that the sample company has a good percentage of audit committee. This is evident from the average value that reached 0.768 .

5. This variable has an average of 0.430 . From this data indicates that the sample company has not done the policy about the percentage of independent commissioners well, it can be seen from the achievement of the average value is only 0.430 .

6 . The sample company ROA variable is 50 which has the highest value of 0.685 with the lowest value of -0.055 and has an average of 0.099 with the standard deviation of 0.144 . These figures illustrate that the company's ability to generate profits when compared to the total assets held vary across companies.

Table 1 - Descriptive statistics

\begin{tabular}{|l|c|c|c|c|c|}
\hline \multicolumn{1}{|c|}{$\mathrm{n} / \mathrm{n}$} & $\mathrm{N}$ & Minimum & Maximum & Mean & STD. Deviation \\
\hline Institutional Ownership & 50 & 0,000 & 0,991 & 0,376 & 0,325 \\
\hline Management Ownership & 50 & 0,000 & 0,920 & 0,036 & 0,132 \\
\hline Audit Committee & 50 & 0,400 & 1,00 & 0,768 & 0,220 \\
\hline Independent Commissioner & 50 & 0,286 & 0,667 & 0,430 & 0,108 \\
\hline ROA & 50 & $-0,055$ & 0,685 & 0,099 & 0,144 \\
\hline Institutional Ownership*ROA & 50 & 0,000 & 0,181 & 0,031 & 0,040 \\
\hline Management Ownership*ROA & 50 & $-0,001$ & 0,094 & 0,004 & 0,016 \\
\hline Audit Committee*ROA & 50 & $-0,022$ & 0,514 & 0,075 & 0,101 \\
\hline Independent Commissioner*ROA & 50 & $-0,018$ & 0,310 & 0,041 & 0,058 \\
\hline Institutional Ownership*ROA & 50 & $-1,001$ & 1,078 & 0,031 & 0,338 \\
\hline Valid N (listwise) & 50 & \multicolumn{5}{l}{-} \\
\hline
\end{tabular}


Normality test. Table 2 shows that the value of Asymp. Sig. for institutional ownership of 0.385; Managerial ownership 0.505; Audit committee 0.860; Independent commissioners 0.957 and ROA 0.995. Of all variables has a value greater than 0.05 . This indicates that all data variables are normally distributed.

Table 2 - Kolmogorov-Smirnov Test Results

\begin{tabular}{|c|c|c|c|c|c|c|}
\hline$n / n$ & & $\begin{array}{l}\text { Institutional } \\
\text { Ownership }\end{array}$ & $\begin{array}{c}\text { Management } \\
\text { Ownership }\end{array}$ & $\begin{array}{c}\text { Audit } \\
\text { Committee }\end{array}$ & $\begin{array}{l}\text { Independent } \\
\text { Commissioner }\end{array}$ & ROA \\
\hline $\begin{array}{l}\mathrm{N} \\
\text { Parameter Normal } \\
\text { Most Extreme } \\
\text { Differences } \\
\text { Kolmogorov-Smirnov Z } \\
\text { Asymp. Sig. (2-tailed) }\end{array}$ & $\begin{array}{l}\text { Mean } \\
\text { Std. Deviation } \\
\text { Absolute } \\
\text { Positive } \\
\text { Negative }\end{array}$ & $\begin{array}{l}50 \\
0,37554 \\
0,325468 \\
0,128 \\
0,128 \\
-0,124 \\
0,906 \\
0,385\end{array}$ & $\begin{array}{l}50 \\
0,03596 \\
0,132224 \\
0,393 \\
0,358 \\
-0,393 \\
0,824 \\
0,505\end{array}$ & $\begin{array}{l}50 \\
0,76772 \\
0,219782 \\
0,275 \\
0,148 \\
-0,275 \\
0,603 \\
0,860\end{array}$ & $\begin{array}{l}50 \\
0,429620 \\
0,107540 \\
0,196 \\
0,196 \\
-0,144 \\
0,510 \\
0,957\end{array}$ & $\begin{array}{l}50 \\
0,09894 \\
0,143633 \\
0,281 \\
0,281 \\
-0,230 \\
0,417 \\
0,995\end{array}$ \\
\hline
\end{tabular}

a. Test distribution is Normal

b. Calculated from data.

Test of Multicollinearity. Multicollinearity test results Table 3 shows the VIF value of each independent variable in the range of 1 with a tolerance value approaching 1 . Thus, it can be concluded that there is no multicollinearity between independent variables.

Table 3 - Multicollinearity Test Results Coefficients ${ }^{a}$

\begin{tabular}{|l|c|c|}
\hline \multicolumn{1}{|c|}{ Model } & \multicolumn{2}{c|}{ Collinearity Statistics } \\
\cline { 2 - 3 } & Tolerance & VIF \\
\hline Institutional Ownership & 0,935 & 1,070 \\
\hline Management Ownership & 0,861 & 1,162 \\
\hline Audit Committee & 0,902 & 1,109 \\
\hline Independent Commissioner & 0,708 & 1,412 \\
\hline ROA & 0,838 & 1,194 \\
\hline Institutional Ownership*ROA & 0,771 & 1,296 \\
\hline Management Ownership*ROA & 0,774 & 1,292 \\
\hline Audit Committee*ROA & 0,843 & 1,187 \\
\hline Independent Commissioner ${ }^{*}$ ROA & 0,873 & 1,145 \\
\hline
\end{tabular}

a. Dependent Variabel: CAR.

Heteroscedasticity Test. In Figure 1 it appears that the existing dots form irregular patterns and spread evenly above or below the zeros on the $Y$ axis. This shows that there is no heteroscedasticity in the regression model in this study.

Scatterplot

Dependent Variable: CAR

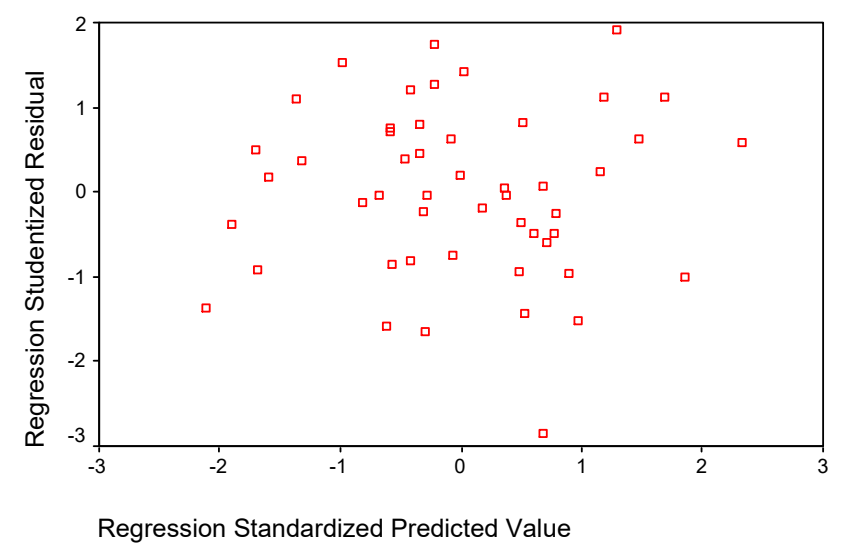

Figure 1 - Scatterplot Heterosceptasticity Test 
Test Autocorrelation. Test results show that there is no autocorrelation problem. Table 3 shows that the autocorrelation test results meet the requirement that there is no problem of autocorrelation both positive and negative in the regression model built. This is seen from the DW count of 1.822 . The number is in the range range between -2 to 2 .

Table 3 - Results of Autocorrelation Testing

Model Summary ${ }^{b}$

\begin{tabular}{|c|c|}
\hline Model & Durbin-Watson \\
\hline 1 & $1.822^{\mathrm{a}}$ \\
\hline
\end{tabular}

a. Predictors: (Constant), Institutional Ownership ${ }^{*} R O A$, Management Ownership ${ }^{\star} R O A$, Audit Committee, Management Ownership, Audit Committe ${ }^{\star} R O A$, Independent Commissioner ${ }^{*} O A$, ROA, Independent Commissioner.

b. Dependent Variable: CAR

Testing Regression Equation Modeling. Table 4 shows that the magnitude of R2 value of 0.034 adjusted R2 is -0.052 . This means that the independent variable can explain the dependent variable of $3.4 \%$. The remaining $96.6 \%$ is explained by other variables not included in the regression model.

Table 4 - Coefficient of Determination

Model Summary

\begin{tabular}{|c|c|c|c|c|}
\hline Model & $\mathrm{R}$ & $\mathrm{R}$ Square & Adjusted R Square & Std. Error of the Estimate \\
\hline 1 & $0.185^{\mathrm{a}}$ & 0.034 & -0.052 & 0.346226 \\
\hline
\end{tabular}

a. Predictors: (Constant), Independent Commissioner, Management Ownership, Audit Committee, Institutional Ownership.

Partial Significance Test Results (Test $t$ Statistics):

Table 5 - Hypothesis test results coefficients ${ }^{a}$

\begin{tabular}{|l|l|l|l|l|l|}
\hline \multicolumn{1}{|c|}{$\mathrm{n} / \mathrm{n}$} & \multicolumn{3}{|c|}{ Unstandardized Coefficients } & \multicolumn{3}{c|}{ Standardized Coefficients } \\
\hline Model & $\mathrm{B}$ & Std. Error & Beta & $\mathrm{t}$ & Sig. \\
\hline (Constant) & -0.088 & 0.307 & & -0.287 & 0.776 \\
\hline Institutional Ownership & 0.074 & 0.174 & 0.072 & 0.427 & 0.672 \\
\hline Management Ownership & 0.335 & 0.387 & 0.131 & 0.865 & 0.392 \\
\hline Audit Committee & 0.001 & 0.238 & 0.001 & 0.006 & 0.995 \\
\hline Independent Commissioner & 0.181 & 0.520 & 0.058 & 0.347 & 0.730 \\
\hline
\end{tabular}

a. Dependent Variable: CAR.

Significance $<0.05$

a. The value of $t$ arithmetic for the institutional ownership variable (X1) is 0.427 with a significance value of 0.672. Institutional ownership has no partial effect on CAR. So the decision taken is H1a rejected.

b. The value of $t$ arithmetic for managerial ownership variable (X2) is 0.865 with a significance value of 0.392 . Partial managerial ownership has no effect on CAR. So the decision taken is $\mathrm{H} 2 \mathrm{a}$ rejected.

c. The value of $t$ arithmetic for audit committee variable (X3) is 0,006 with significance value 0,995. Audit committee partially has no effect on CAR. So the decision taken is H3a rejected.

d. The value of $t$ arithmetic for independent commissioner variable (X4) is 0.347 with a significance value of 0.730, independent Commissioner partially has no effect on CAR. So the decision taken is H4a rejected.

The test results on the regression coefficients for the entire sample based on Table 5.7 yield the following model of regression equation:

$$
C A R=-0,088+0,074 K P I N+0,335 K P M J+0,001 K M A U+0,181 K M I N
$$

Moderating Regression Analysis (MRA). Table 6 shows that the magnitude of $\mathrm{R} 2$ value of 0.657 adjusted R2 is 0.580 . Thus, the independent variable can explain the dependent variable of $65.7 \%$. The remaining $34.3 \%$ is explained by other variables not included in the regression model. 
Table 6 - Hypothesis Test Results

Model Summary

\begin{tabular}{|c|c|c|c|c|}
\hline Model & R & R Square & Adjusted R Square & Std. Error of the Estimate \\
\hline 1 & $0.811^{\mathrm{a}}$ & 0.657 & 0.580 & 0.218764 \\
\hline
\end{tabular}

a. Predictors: (Constant), Institutional Ownership ${ }^{\star} R O A$, Independent Commissioner, Management Ownership, Audit Committee, Institutional Ownership, Institutional Ownership ${ }^{\star} R O A$, , Audit Committee ${ }^{\star} R O A$, Independent Commissioner ${ }^{*} O A, R O A$.

Partial Significance Test Result (Test $t$ Statistics). Partial test is used to determine the influence of each independent variable and control variable to the dependent variable.

Table 7 - Hypothesis test results

Coefficients $^{\mathrm{a}}$

\begin{tabular}{|l|c|c|c|c|c|}
\hline \multirow{2}{*}{ Model } & \multicolumn{2}{|c|}{$\begin{array}{c}\text { Unstandardized } \\
\text { Coefficients }\end{array}$} & \multicolumn{3}{c|}{$\begin{array}{c}\text { Standardized } \\
\text { Coefficients }\end{array}$} \\
\cline { 2 - 6 } & $\mathrm{B}$ & Std. Error & Beta & $\mathrm{t}$ & Sig. \\
\hline (Constant) & -0.255 & 0.228 & & -1.118 & 0.270 \\
\hline Institutional Ownership & 0.270 & 0.164 & 0.261 & 1.650 & 0.107 \\
\hline Management Ownership & -2.893 & 1.029 & -1.133 & -2.812 & 0.008 \\
\hline Audit Committee & -0.234 & 0.189 & -0.153 & -1.240 & 0.222 \\
\hline Independent Commissioner & 0.672 & 0.421 & 0.214 & 1.598 & 0.118 \\
\hline ROA & 2.915 & 2.629 & 1.240 & 1.109 & 0.274 \\
\hline Institutional Ownership*ROA & -1.341 & 1.537 & -0.160 & -0.873 & 0.388 \\
\hline Management Ownership*ROA & 32.830 & 10.247 & 1.527 & 3.204 & 0.003 \\
\hline Audit Committee* ROA & 3.445 & 1.555 & 1.028 & 2.215 & 0.033 \\
\hline Independent Commissioner ${ }^{*}$ ROA & -10.960 & 6.089 & -1.869 & -1.800 & 0.079 \\
\hline
\end{tabular}

a. Dependent Variable: CAR

Significance $>0.05$

Table 7 can be concluded as follows:

a. The value of $t$ arithmetic for institutional ownership variable moderated by ROA is -0.873 with a significance value of 0.388. Thus, institutional ownership moderated by ROA has no partial effect on CAR. So the decision taken is $\mathrm{H} 1 \mathrm{~b}$ rejected.

b. The value of $t$ arithmetic for managerial variables moderated by ROA is 3.204 with a significance value of 0.003. Thus, the managerial ownership moderated by ROA partially influences the CAR. So the decision taken is $\mathrm{H} 2 \mathrm{~b}$ accepted.

c. The value of $t$ arithmetic for audit committee variables moderated by $R O A$ is 2,215 with a significance value of 0.033. Thus, the audit committee moderated by ROA partially influences the CAR. So the decision taken is H3b accepted.

d. The value of $t$ arithmetic for independent commissioner variables moderated by ROA is -1.800 with a significance value of 0.79 . Thus, an independent commissioner moderated by ROA has no partial effect on the CAR. So the decision taken is H4b rejected.

The result of the description above shows that in this regression equation model there is influence to partially variable which have significant effect to CAR, that is managerial ownership variable with significance value 0,003 and audit committee variable with significance value 0,033 while institutional ownership variable with value of significance 0,388 and variable of commissioner Independent with a significance value of 0.079 is not significant. So it can be concluded that ROA is a moderating variable, but ROA is not a direct moderation variable, but rather an indirect moderation variable. The test results on the regression coefficients for the entire sample based on Table 5.8 yield the following model of regression equation:

$$
\begin{gathered}
C A R=-0,255+0,270 K P I N-2,893 K P M J-0,234 K M A U+0,672 K M I N+2,915 R O A-1,341(K P I N \\
\left.{ }^{*} R O A\right)+32,830\left(K P M J{ }^{*} R O A\right)+3,445\left(K M A U{ }^{*} R O A\right)-10,960\left(K M I N{ }^{*} R O A\right)+e
\end{gathered}
$$

\section{DISCUSSION OF RESULTS}

\section{Effect of Institutional Ownership on CAR}


The results show that the proportion of institutional ownership does not affect the stock CAR. The higher institutional ownership of the company does not necessarily encourage the CAR of Shares to be higher. Based on Agency Theory which states that there is a difference of interest between Agent and Principal, it is expected that the high proportion of institutional ownership is expected to take a role in improving investor confidence in the issue derived from Agency Theory. But the research results are different from the theories already mentioned. In line with the results of research conducted by Sudarma (2003) who found the results of institutional ownership negatively affect the value of the company.

\section{Effect of Institutional Ownership on CAR moderated by ROA}

$\mathrm{ROA}$ is the ratio of corporate profitability that describes the company's ability to generate profits compared to total assets owned by the company. The higher ROA ratio a company can attract investors to invest. In line with this is in accordance with the signaling theory put forward by experts, where the company, provide a positive signal so that investors respond with a positive also reflected in the CAR. But the results of the study contradict the Signaling Theory, the results show that ROA, can not moderate the influence of institutional ownership of CAR Shares. Although the proportion of institutional ownership of a company that is high but not necessarily can attract investors to invest when viewed from the side of ownership of its shares. The higher proportion of institutional ownership of the company does not necessarily encourage higher stock CARs. However, the ROA variable can deliver the institutional ownership variable to the stock CAR. This is evidenced by the second hypothesis testing $(\mathrm{H} 1 \mathrm{~b})$ which states that the ROA becomes a moderator variable relationship between institutional ownership of the stock CAR.

\section{Effect of Management Ownership on CAR}

The results show that management ownership does not affect the stock CAR. The higher ownership of the company's management is not necessarily pushed CAR Shares to be higher. Researchers suspect that there are other variables that can strengthen or weaken the relationship between management ownership of stock CARs. The results of this study contradict the results of research conducted by Rahayu and Faisal (2005) states that the greater the proportion of ownership ownership management in a company then management will work harder to meet the interests of shareholders who also is himself. But the same result with Sudarma (2003) found that managerial ownership had no significant effect on firm value.

\section{Effect of Ownership CAR management is moderated by ROA}

ROA is the ratio of corporate profitability that describes the company's ability to generate profits compared to total assets owned by the company. The higher ROA ratio a company can attract investors to invest. In line with this is in accordance with the signaling theory put forward by experts, where the company, provide a positive signal until the investors responded with a positive also reflected in the CAR. In line with the Signaling Theory, the results show that ROA can moderate the effect of management ownership on stock CARs. With the increasing ratio of high management ownership of a company certainly can attract investors to make an investment when viewed from the side of ownership of its shares. The higher Management Ownership of the company turned out to be able to encourage CAR shares to be higher as well. So it can be concluded ROA can deliver ownership of management to CAR. This is evidenced by the testing of hypotheses to the four H2b which states that the variable ROA be a moderator variable relationship between management ownership of the stock CAR.

\section{Effect of the Audit Committee on CAR.}

The results show that audit committee has no effect on stock CAR. The higher proportion of corporate audit committees does not necessarily lead to higher CAR shares. This is evidenced by the hypothesis testing of the fifth $\mathrm{H} 3 \mathrm{a}$. Researchers suspect that there are other variables that can strengthen or weaken the relationship between the audit committee and the stock CAR. The results of this study in line with the results of research conducted by Ramdiani and Yadnyana (2013) concluded that statistically the number of members of the audit committee does not affect the stock price. However, the results of research contradict the results of Turley and Zaman (2004) research that examines the effect of corporate 
governance and audit committees, the results of the study found that evidence indicates a positive relationship between the existence of the audit committee with the quality of financial statements and firm performance against stock prices.

The influence of the Audit Committee influences the CAR is moderated by ROA

$\mathrm{ROA}$ is the ratio of corporate profitability that describes the company's ability to generate profits compared to total assets owned by the company. The higher ROA ratio a company can attract investors to invest. In line with this is in accordance with the signaling theory put forward by experts, where the company, give a positive signal until the investors responded with a positive as well. In line with the Signaling Theory, the results of the study show that ROA can moderate the influence of audit committee's proportion to CAR of Shares. With the proportion of audit committee of a high company certainly can attract investors to invest when viewed from the proportion of audit committee. The higher the proportion of audit committees the company can turn CAR shares higher. So it can be concluded ROA variable can deliver variable audit committee to stock CAR. This is evidenced by the testing of the six hypothesis $\mathrm{H} 3 \mathrm{~b}$ states that the ROA becomes a moderator variable relationship between the audit committee on the CAR.

\section{Influence of Independent Commissioner's Influence on CAR}

The results show that independent commissioners have no effect on the CAR of Shares. The higher the company's independent commissioner is not necessarily pushing the stock CAR to be higher. H4a's seventh hypothesis testing states that independent commissioners can not affect the CAR of Shares. Based on Agency Theory which states that there is a difference of interest between Agent and Principal, it is expected that the high independent commissioner's proportion is expected to take a role in improving investor confidence in the issue derived from Agency Theory. But the research results are different from the theories already mentioned. Researchers suspect that there are other variables that either strengthen or even weaken the relationship between independent commissioners against stock CARs. In line with the results of research conducted by Ramdiani and Yadyana (2013) concluded that statistically the proportion of independent commissioners has no effect on stock prices.

Effect of Independent Commissioners on Cumulative Abnormal Return Shares are moderated by ROA

ROA is the ratio of corporate profitability that describes the company's ability to generate profits compared to total assets owned by the company. The higher ROA ratio a company can attract investors to invest. In line with this is in accordance with the signaling theory put forward by experts, where the company, provide a positive signal until the investors responded with a positive also reflected in the CAR. But the results of the research differ from existing theories, which show that the ROA variable can not moderate the influence of independent commissioners against the stock CAR. Although the high proportion of independent commissioners of a corporation may not necessarily attract investors to invest in terms of the proportion of independent commissioners. The higher the proportion of the company's independent commissioners does not necessarily push CAR shares higher. So it can be concluded ROA variable can not deliver independent commissioner to stock CAR. This is evidenced by the testing of the eighth hypothesis H4b.

\section{CONCLUSION AND SUGGESTIONS}

The partial test results show that the factors of each proportion: institutional ownership, management ownership, audit committee, and independent commissioner have no effect on CAR. Corporate governance does not have an impact in raising the CAR because the implementation of corporate governance in Indonesia still has not given an autonomous outcome considering the process in corporate governance practices takes time to know its benefits. So researchers suspect that there are other factors that can strengthen or weaken the relationship between institutional ownership, management ownership, audit committees, and independent commissioners of the CAR. This is evidenced by the results of research on hypothesis $2 \mathrm{~b}$ that proved to have a positive value significantly between management ownership with CAR moderated by ROA. This means that an increase in the proportion of 
management ownership is followed by a CAR increase which is supported by an increase in ROA ratio. In addition, hypothesis $3 \mathrm{~b}$ also has a significant positive result. ROA can moderate the relationship between audit committees to CAR. Which means that, the increase in the proportion of audit committees is followed by the increase in CAR supported by the increase in ROA ratio.

The first limitation of the research is the unavailability of data, both annual reports and stock prices. The sample used should be all companies included in LQ 45 period 2015-2016. Researchers can only find 50 annual reports of companies, either from the source website of the Indonesia Stock Exchange or related company website. In addition, there are some companies whose stock price data can not be found.

Further research can be developed using cross-sectional data types. By extending the study period. This is done in order to obtain more varied results again so as to increase the results of empirical testing that has been done before.

\section{REFERENCES}

1. Barclay, M.J. \& C.G. Holderness. 1990. Private benefits from control of public corporations, Journal of Financial Economics, Vol. 2. No. 25. Hal. 371-395.

2. Brigham, Eungene F. \& Joel F. Houston. 2009. Fundamentals of Financial Management (Dasar-Dasar Manajemen Keuangan). Buku 1. Edisi 10. Jakarta: Salemba Empat. Hal. 34.

3. Budiharjo, Roy. 2016. Pengaruh good corporate Governance Terhadap Return Saham dengan Profitabilitas sebagai Variabel Intervening dan Moderating (Studi Empiris Pada Perusahaan Peraih CGPI Yang Terdaftar di Bursa Efek Indonesia Tahun 2010-2012). Tekun. Vol VII. No.01.

4. Carningsih. 2009. Pengaruh Good Corporate Governance Terhadap Hubungan Antara Kinerja Keuangan Dengan Nilai Perusahaan (Studi Kasus Pada Perusahaan Property dan Real Estate yang Terdaftar di Bursa Efek Indonesia). SKRIPSI. Jakarta: Jurusan Akuntansi Fakultas Ekonomi: Universitas Gunadarma.

5. Chtourou, SM., Jean Bedard, \& Lucia Courteau. 2001. Corporate Governance and Earnings Management. Working Paper. Universite Laval, Quebec City, Canada.

6. Cyert, R.M., \& March, J.G. 1998. Behavioral Theory of the Firm, Wiley-Blackwell. Edisi ke-2. Hal. 117.

7. Ghozali, Imam. 2016. Aplikasi Analisis Multivariate dengan Program SPSS. Cetakan Keempat: Badan Penerbit Universitas Diponegoro. Semarang. Hal. 11.

8. Gompers, P.A., Ishii, J.L., \& Metrick, A. 2001. Corporate Governance and Equity Prices, Working Paper.

9. Gradiyanto, Andrean. 2012. Pengaruh Komite Audit Terhadap Praktik Manajemen Laba (Studi Kasus Pada Perusahaan Manufaktur Di Bursa Efek Indonesia Tahun 2009 2011). Accounting Business Management Journal. Vol 3. HIm 87-91.

10. Gradiyanto, Andrean. 2012. Pengaruh Komite Audit Terhadap Praktik Manajemen Laba (Studi Kasus Pada Perusahaan Manufaktur Di Bursa EfekIndonesia Tahun 2009 - 2011). Accounting Business Management Journal.

11. Guna, Welvin I, \& Arleen Herawaty. 2010. Pengaruh Mekanisme Good Corporate Governance, Independensi Auditor, Kualitas Audit, dan Faktor Lainnya Terhadap Manajemen Laba. Jurnal Bisnis dan Akuntansi. Vol. 12. Hal. 34.

12. Harahap, Sofyan Syafri. 2009. Analisis Kritis Atas Laporan Keuangan. Jakarta: Raja Grafindo Persada. Hal 77.

13. Hartono, Jogiyanto. 2009. Teori Portofolio dan Analisis Investasi. Edisi Keenam. Yogyakarta: Fakultas Ekonomika dan Bisnis Universitas Gadjah Mada. Hal. 558.

14. Holderness, C.G. \& Sheehan, D.P. 1988. The role of majority shareholders in publicly held corporations: an exploratory analysis, Journal of Financial Economics. Vol. 20. No. 2. Hal. 317-346.

15. Husni, Raudhatul. 2012. Pengaruh Mekanisme Good Corporate Governance, Leverage dan Profitabilitas Terhadap Manajemen Laba (Studi Empiris Perusahaan Property Dan 
Real Estate Yang Terdaftar Di Bursa Efek Indonesia Tahun 2008-2010. Jurnal Ekonomi dan Bisnis. Vol 2. No 2. Hal 77-93.

16. Indriantoro, Nur \& Bambang Supomo. 2011. Metodologi Penelitian Bisnis untuk Akuntansi dan Manajemen. Edisi Pertama. Yogyakarta: BPFE. HIm 89.

17. Indriastuti, Maya. 2012. Pengaruh Prinsip - prinsip Corporate Governance terhadap Abnormal Return (Studi Kasus pada Perusahaan yang melakukan SEO dan Listing di BEI). Solusi. Vol 11. No. 1. HIm $89-102$.

18. Jensen, Michael C. \& William H. 1976. Meckling. Theory of the Firm: Managerial Behavior, Agency Costs and Ownership Structure. Journal of Financial Economics. Hal. 135, 305-360.

19. Jogiyanto H.M. 2015. Teori Portofolio dan Analisis Investasi. Edisi Ketujuh. Yogyakarta: BPFE. HIm 416.

20. Kartikasari, Desi. 2011. Pengaruh Good Corporate Governance terhadap Manajemen Laba (Studi Empiris pada Perusahaan Perbankan di BEI Tahun 2007 - 2009. Accounting Business Management Journal. Vol 2. HIm 112-130.

21. Lokollo, Antonius \& Muchamad Syafruddin. 2013. Pengaruh ManajamenModal Kerja Dan Rasio Keuangan Terhadap Profitabilitas Pada IndustriManufaktur Yang Terdaftar Di Bursa Efek Indonesia (Bei) Tahun 2011. Diponegoro journal of accounting. Vol. 2. No. 2.

22. Mamduh M. Hanafi \& Abdul Halim. 2005. Analisis Laporan Keuangan. AMP-YKPN. Yogyakarta. Hal. 97.

23. Naftalia, Veliandina Chivan. 2013. Pengaruh Leverage Terhadap Manajemen Laba dengan Corporate Governance Sebagai Variabel Pemoderasi. Accounting Business Management Journal. Vol 1. HIm 35-51.

24. Nasution, Marihot \& Doddy Setiawan. 2007. Pengaruh Corporate Governance Terhadap Manajemen Laba di Industri Perbankan Indonesia. Simposium Nasional ke X Makasar.

25. Ningsaptiti, Restie. 2010. Analisis Pengaruh Ukuran Perusahaan dan Mekanisme Corporate Governance Terhadap Manajemen Laba (Studi Empiris pada Perusahaan Manufaktur yang terdaftar di Bursa Efek Indonesia 2006-2008). Accounting Business Management Journal. Vol 1. Hal 113-127.

26. Nogi, S. Hessel, Tangkilisan. 2003. Mengelola Kredit Berbasis Good Corporate Governance. Yogyakarta: Balairung \& Co. Hal 116.

27. Owen, D. 2005. CSR after Enron: A Role for The Academic Accounting Profesion?. European Accounting Review. Vol. 14. No 2. Hal 293-404.

28. Pound, J. 1988. Proxy Content and the Efficiency of Shareholder Oversight. Journal of Financial Economics. Vol. 20. Hal. 237-265.

29. Pratiwi, Nining \& Suryanawa, I. Kt. 2014. Pengaruh Good Corporate Governance dan Corporate Social Responsibility Disclosure Pada Return Saham. E-Jurnal Akuntansi Universitas Udayana. Vol. 9, No. 2.

30. Rahayu, Dyah Sih \& Faisal. 2005. Pengaruh Kepemilikan Manajerial dan Institusional pada Struktur Modal Perusahaan. Jurnal Bisnis dan Akuntansi. Vol. 7. No. 2. Hal. 190203.

31. Ramdiani, Ni Nyoman dan Yadnyana, I Ketut. 2013. Pengaruh Penerapan Corporate Governance dan Kinerja Keuangan Pada Harga Saham Perbankan yang Terdaftar di Bursa Efek Indonesia Tahun 2009-2011. Bali. E-Jurnal Fakultas Ekonomi: Universitas Udayana. Vol 3. Hal 217-232.

32. Robert, Gordon S \& Yuan, Liangzeng., 2006. Does Institutional Ownership Affect the Cost of Bank Borrowing. Journal of Social Science Reasearch Network. Vol 5. Hal 314347.

33. Sarwoko. 2005. Dasar-dasar Ekonometrika. Yogyakarta: Andi. Hal. 286

34. Sekaran, Uma. 2006. Metodologi Penelitian Untuk Bisnis. Jakarta: Salemba Empat. Hal 77, 162, 177.

35. Shleifer, A. \& R.W. Vishny. 1997. A Survey of Corporate Governance. Journal of Finance. Vol 52. No 2. Hal 737-763. 
36. Siallagan, Hamonangan dan Mas. Ud. Machfoedz. 2006. Mekanisme Corporate Governance, Kualitas Laba dan Nilai Perusahaan. Artikel Simposium Nasional Akuntansi (SNA) IX, Padang.

37. Soliha, E. \& Taswan. 2002. Pengaruh Kebijakan Hutang terhadap Nilai Perusahaan serta Beberapa Faktor yang Mempengaruhinya. Jurnal Bisnis dan Ekonomi. Vol. 9. No. 2. Hal. 149-163.

38. Sudarma, Made. 2003. Pengaruh Struktur Kepemilikan Saham, Faktor Intern, Faktor Estern terhadap Struktur Modal dan Nilai Perusahaan. Disertasi Program Pascasarjana, Universitas Brawijaya. Malang.

39. Susiana \& Arleen Herawaty. 2007. Analisa Pengaruh Indepedensi, Mekanisme Corporate Governance, Kualitas Audit Terhadap Integritas Laporan Keuangan. SNA X. Universitas Hasanudin Makasar.

40. Sutedi, Adrian. Good Corporate Governance. 2011. Jakarta: Sinar Grafika. HIm 50.

41. Tristiarini, Nila, 2005, Pengaruh Penerapan Corporate Governance terhadap Abnormal Return Pada Saat Pengumuman Laporan Keuangan 2003, Tesis, Universitas Diponegoro, Semarang.

42. Turley S., Zaman M. 2007. Audit committee effectiveness: informal processes and behavioural effectsAccounting. Auditing \& Accountability Journal. Vol. 20. No. 5, Hal. 765-788.

43. Ujiyanto, Muh. Arief \& Pramuka, Bambang Agus. 2007. Mekanisme Corporate Governance, Manajemen Laba dan Kinerja Keuangan (Studi Pada Perusahaan go public Sektor Manufaktur). SNA X. Makasar.

44. Untung, Edi \& Sugiono Arif. 2008. Panduan Praktis dan Dasar Analisis Laporan Keuangan. Grasindo. Jakarta. HIm 71.

45. Van Horne, James C. and John M. Wachowicz. 2005. Fundamentals of Financial: Management Prinsip-Prinsip Manajemen Keuangan. Translated by: Dewi Fitriasari \& Deny Arnos Kwary. Penerbit Salemba Empat: Jakarta. Hal. 216. 